\title{
Short-term dynamics of soil carbon, microbial biomass, and soil enzyme activities as compared to longer-term effects of tillage in irrigated row crops
}

\author{
Daniel Geisseler • William R. Horwath
}

Received: 6 March 2009/Revised: 1 May 2009 /Accepted: 5 May 2009 / Published online: 25 August 2009

(C) The Author(s) 2009. This article is published with open access at Springerlink.com

\section{Introduction}

The effects of disturbance on soil quality are difficult to determine because soil is inherently variable and physical and chemical soil properties change too slowly to reflect recent management history. Microbial and biochemical soil properties have been suggested as early and sensitive indicators of changes in soil quality as they manifest themselves over shorter timescales and are central to the ecological function of a soil (Karlen et al. 1994; Bandick and Dick 1999). Soil enzyme activities in particular are increasingly used as indicators of soil quality because of their relationship to decomposition and nutrient cycling, ease of measurement, and rapid response to changes in soil management (Dick 1994; Dilly et al. 2003). In a long-term study, Kandeler et al. (1999) found that enzyme activities were significantly increased in the top $10 \mathrm{~cm}$ of the profile after only 2 years of minimum and reduced tillage compared to conventional tillage. In contrast, significant effects of tillage treatments on microbial biomass, nitrogen (N) mineralization, and potential nitrification were not observed until after 4 years.

Soil disturbance, however, is only one of the many factors affecting soil microbial and biochemical properties. Seasonal fluctuations in soil moisture, temperature, and substrate availability can also have large effects on microbial biomass and activity. Franzluebbers et al. (1994) found that soil microbial biomass carbon $\left(\mathrm{C}_{\text {mic }}\right)$ changed significantly during the cropping season in all crop sequences

D. Geisseler $(\bowtie) \cdot$ W. R. Horwath

Department of Land, Air, and Water Resources,

University of California, Davis,

PES Building, 1 Shields Ave,

Davis, CA 95616, USA

e-mail: djgeisseler@ucdavis.edu and tillage regimes under investigation. Bausenwein et al. (2008) also reported significant effects of sampling date on $\mathrm{C}_{\mathrm{mic}}$ and enzyme activities under minimum tillage. These observations raise the question of whether microbial and biochemical properties are affected by too many factors and fluctuate too much during the course of a season to be sensitive indicators of tillage-induced effects on soil quality.

In general, conservation tillage (CT) practices leave a significant amount of plant residue on the soil surface. This results in an increased soil organic matter content in the topsoil, which in turn leads to higher microbial biomass and activity. This increase in organic matter content in the topsoil however is often offset with a decrease in lower soil layers (Dick 1992; Omidi et al. 2008). Franzluebbers (2002) suggested using changes in soil organic C with depth rather than the total amount of soil organic $\mathrm{C}$ in the profile as indicators of tillage-induced effects on soil properties. The stratification ratio, calculated by dividing the value for a soil property in the topsoil by its value in the subsoil, could not only be a more sensitive way to measure tillage-induced changes, but it also normalizes for differences in climatic conditions and soil types between study sites. Because surface organic matter is essential to erosion control and water infiltration, the degree of stratification is directly linked to soil quality (Franzluebbers 2002).

The objective of this study was to compare short-term dynamics of soil $\mathrm{C}$, microbial biomass, and soil enzyme activities with longer-term effects of tillage in irrigated row crops in order to determine how environmental factors affect the use of these properties as sensitive indicators of tillage-induced changes in soil quality. A field trial was designed to test the following hypotheses: (1) enzyme activities and microbial biomass $\mathrm{N}\left(\mathrm{N}_{\mathrm{mic}}\right)$ respond more rapidly to differences in tillage treatments than total soil $\mathrm{C}$. 
(2) Enzyme activities and $\mathrm{N}_{\text {mic }}$ are more affected by environmental factors than total soil $\mathrm{C}$, resulting in a larger temporal variability. (3) The vertical distribution of soil properties in the profile has a lower temporal variability than the average value in the top $30 \mathrm{~cm}$ of the profile, making it a more sensitive indicator of tillage-induced effects than the average values in the top $30 \mathrm{~cm}$ of the profile. The activities of protease, $\beta$-glucosidase, and $\beta$-glucosaminidase were chosen because these enzymes are involved in the degradation of proteins, cellulose, and chitin, respectively, which are among the most abundant organic compounds available to soil microorganisms.

\section{Material and methods}

\section{Experimental site}

The study was carried out at the Long-Term Research on Agricultural Systems site, near Davis, CA, USA. The site has a Mediterranean climate with a mean annual temperature of $15.7^{\circ} \mathrm{C}$ and $440-\mathrm{mm}$ precipitation (Western Regional Climate Center, online at http://www.wrcc.dri.edu). Soils at the site include Rincon silty clay loam (fine, montmorillonitic, thermic Mollic Haploxeralf) and Yolo Silt Loam (fine-silty, mixed, superactive, nonacid, thermic Mollic Xerofluvent; Soil Survey Staff 1997) and have a sand content of $15-28 \%$ and a clay content of $26-32 \%$ (pipette method; Gee and Bauder 1986). The average $\mathrm{pH}$, measured in a 1:2 soil-water solution following a 30-min equilibration, was 7.1. It increased by 0.1 unit from the surface to a depth of $30 \mathrm{~cm}$ and was about 0.1 units higher in the soil under CT compared to the standard tillage soil. The bulk density, measured in fall 2007 , was $1.27 \mathrm{~g} \mathrm{~cm}^{-3}$ in the top $15 \mathrm{~cm}$ and 1.49 in the 15-30-cm layer, with no differences between the two tillage systems.

Plots under a corn-tomato rotation with a winter cover crop were chosen for the study. Crops are planted on beds and irrigation water is furrow run. Until 2006, a mixture of vetch (Vicia dasycarpa) and peas (Pisum sativum) was used as the winter cover crop (Denison et al. 2004). In winter 2006/2007, oat (Avena sativa) was added to the mixture. The two tillage treatments were established in 2002. Tillage is performed with a bedpreserving disk harrow to a depth of 15 to $20 \mathrm{~cm}$ and one pass with a Cambridge roller to compact the soil surface. In the ST treatment, the plots are tilled in spring and fall before the planting of the main crop and the winter cover crop, respectively. In the CT system, no tillage is performed in fall; instead, the corn residue is chopped and left on the soil surface. In spring, a strip in the center of each bed, $30 \mathrm{~cm}$ wide and $8 \mathrm{~cm}$ deep, is tilled before the tomatoes are transplanted. Before the corn is planted, the beds are tilled as in the ST system. In 2007, however, no tillage was performed in the CT microplots used for this study, leaving the cover crop residues on the soil surface.

When mowed on April 7, the cover crop in both tillage systems had produced an aboveground biomass of $9.2 \mathrm{tha}^{-1}$ and was composed of $74 \%$ oats, $8 \%$ legumes (predominantly vetch), and $18 \%$ weeds, dominated by fiddleneck (Amsinckia spp.) and common chickweed (Stellaria media). The total $\mathrm{N}$ content of the cover crop was $1.1 \%$ and the $\mathrm{C}$ to $\mathrm{N}$ ratio 37 . The ST plots were tilled on May 1 and corn planted on May 14 in both tillage systems (two rows per bed). The plots were irrigated every 7 to 10 days depending on evapotranspiration. The corn received $56 \mathrm{~kg}$ $\mathrm{N} \mathrm{ha}^{-1}$ in the form of ammonium sulfate on June 18. Granular fertilizer was applied in a band at a distance of $5-10 \mathrm{~cm}$ from the corn row and at a depth of about $3 \mathrm{~cm}$. The corn was harvested in late September.

\section{Soil sampling}

Each tillage treatment was replicated three times. Microplots ( $5 \mathrm{~m}$ long, three beds wide) within the main plots were assigned to the study. Soil samples from the top $30 \mathrm{~cm}$ of the central bed were taken five times between April and September 2007. Samples were taken from the part of the bed between the corn rows to avoid the fertilizer bands. Five cores $(1.5-\mathrm{cm}$ diameter) were combined for each sample. The cores were divided into three layers, $0-5$, 515 , and $15-30 \mathrm{~cm}$. The samples were stored in plastic bags and kept on ice for transport back to the laboratory, sieved through a $4-\mathrm{mm}$ sieve, stored at $4^{\circ} \mathrm{C}$, and analyzed within $24 \mathrm{~h}$ of collection.

\section{Soil analysis}

Oven-dried and ball-milled soil samples were analyzed for total $\mathrm{C}$ and $\mathrm{N}$ content by dry combustion on a Carlo Erba CNS analyzer NA 1500 series 2 .

Microbial biomass $\mathrm{N}$ was determined on field moist samples using the chloroform fumigation extraction method (Horwath and Paul 1994) followed by determination of dissolved $\mathrm{N}$ in the extracts with the alkaline persulfate oxidation method (Cabrera and Beare 1993). Briefly, samples of $6 \mathrm{~g}$ were weighed into glass vials and fumigated with chloroform for 5 days. Dissolved $\mathrm{N}$ was extracted with $0.5 \mathrm{M}$ potassium sulfate $\left(\mathrm{K}_{2} \mathrm{SO}_{4}\right.$; $5 \mathrm{~mL} \mathrm{~g}^{-1}$ soil) and the suspension filtered (Fisherbrand filter paper, Q5). Controls were treated identically except that they were not fumigated. An aliquot $(0.5 \mathrm{~mL})$ of the extract was then mixed with $0.5 \mathrm{~mL}$ of persulfate reagent as described by Cabrera and Beare (1993) and the nitrate concentration determined using a single reagent 
method (Doane and Horwath 2003). Microbial biomass N was calculated by dividing the difference in $\mathrm{N}$ content between the fumigated and unfumigated sample by 0.68 to account for an incomplete $\mathrm{N}$ extraction (Horwath and Paul 1994).

Enzyme activities were assayed on $1 \mathrm{~g}$ of field moist soil in glass vials with screw caps. Protease, $\beta$-glucosidase, and $\beta$-glucosaminidase activity were determined following the procedures described by Ladd and Butler (1972), Tabatabai (1994), and Parham and Deng (2000), respectively. The assay conditions are summarized in Table 1 .

All results are expressed on a moisture-free basis. Moisture content was determined by drying the soil samples at $105^{\circ} \mathrm{C}$ for $24 \mathrm{~h}$.

Data analysis

Based on the soil properties measured in the three layers, the average values for the whole $30-\mathrm{cm}$ profile were calculated using the weighted average of the values measured in the different layers corrected for differences in bulk density. The stratification ratio was calculated by dividing the values measured in the $0-5-\mathrm{cm}$ layer by the values for the $15-30-\mathrm{cm}$ layer.

Statistical analyses were conducted with SAS (SAS Institute 1990), using the general linear model procedure for analysis of variance. The data set was analyzed as a split plot design with tillage treatment as the main factor and depth or sampling date as subfactors. The assumptions of the statistical models were tested for every data set. Normality of the residuals was evaluated graphically and with the Shapiro-Wilk test. Homogeneity of variances was tested by plotting the residuals vs. the predicted values and with Levene's test. If necessary, the data were transformed. When data transformation did not result in homogeneous variances, the MIXED procedure with the repeated statement was used. This procedure does not require homogeneous variances across all treatments (Littell et al. 2006). Mean comparisons were performed using the Tukey test, which controls the experiment-wise type I error rate $\alpha$ (SAS Institute 1990). Effects were considered significant for $P<0.05$.

\section{Results}

In April, the top $5 \mathrm{~cm}$ of the profile and the subsoil had gravimetric soil moisture contents of $10 \%$ and $13 \%$, respectively, with no differences between the two tillage systems. When the corn was planted on May 14, the surface of the CT soil had a gravimetric moisture content of $19 \%$, compared to $15 \%$ in the surface layer of the ST soil. Below $5 \mathrm{~cm}$, the gravimetric moisture content was $22 \%$ in both tillage systems. During the main growing season, the corn was furrow-irrigated every 7 to 10 days. The irrigation water did not wet the surface soil of the beds between the corn rows. By July, the gravimetric moisture content of the top $5 \mathrm{~cm}$ had decreased to about $8 \%$ in both tillage treatments, while the moisture content in the subsoil samples averaged $15 \%$ without any significant differences between the tillage treatments.

The average $\mathrm{C}$ content in the top $30 \mathrm{~cm}$ of the soil profile was 10.4 and $10.6 \mathrm{~g} \mathrm{~kg}^{-1}$ dry soil in the ST and CT soil, respectively, with no significant differences between the two tillage systems nor between sampling dates (Table 2). Total soil C decreased significantly with depth at all sampling dates and in both tillage systems (Fig. 1). In general, the total $\mathrm{C}$ content in the top $5 \mathrm{~cm}$ tended to be higher in the CT soil, while below $5 \mathrm{~cm}$ the $\mathrm{ST}$ soil contained more $\mathrm{C}$. The stratification ratio for total soil $\mathrm{C}$ averaged 1.49 and 1.31 in the CT and ST soil, respectively. With the exception of the samples taken in April, the difference in the stratification ratio between the two tillage systems was not significant, nor did the stratification ratio change significantly over time (Table 3 ).

The average $\mathrm{N}_{\text {mic }}$ content in the soil profile changed significantly over time, being considerably lower later in the growing season. However, there were no significant differences between tillage treatments at any sampling date (Table 2). In April, $\mathrm{N}_{\text {mic }}$ deceased slightly but not significantly with depth in the CT soil while in the ST soil it was highest in the 5-15-cm layer (Fig. 1). Microbial biomass $\mathrm{N}$ was higher in the surface layer of the $\mathrm{CT}$ soil compared to the ST soil. Below a depth of $5 \mathrm{~cm}$, however, there were no differences in $\mathrm{N}_{\text {mic }}$ between the tillage treatments. At planting, $\mathrm{N}_{\text {mic }}$ had doubled in the top $5 \mathrm{~cm}$ of the CT soil but remained at the same level in the lower

Table 1 Assay conditions used to determine the different soil enzyme activities

\begin{tabular}{|c|c|c|c|c|c|}
\hline Enzyme activity & Substrate used & Buffer & $\mathrm{pH}$ & Temperature & Time (h) \\
\hline Protease (EC 3.4.2.21-24) & Na-caseinate $(10 \mathrm{~g} / \mathrm{L})$ & 0.1 M Tris & 8 & $50^{\circ} \mathrm{C}$ (in water bath) & 2 \\
\hline$\beta$-glucosidase (EC 3.2.1.21) & $p$-nitrophenyl $\beta$-D-glucoside $(0.01 \quad \mathrm{M})$ & $0.1 \mathrm{M}$ acetate & 5 & $22^{\circ} \mathrm{C}$ (on reciprocal shaker) & 1 \\
\hline$\beta$-glucosaminidase (EC 3.2.1.30) & $\begin{array}{l}p \text {-nitrophenyl } N \text {-acetyl- } \beta \text {-D- } \\
\text { glucosaminide }(0.002 \mathrm{M})\end{array}$ & $0.1 \mathrm{M}$ acetate & 5 & $22^{\circ} \mathrm{C}$ (on reciprocal shaker) & 2 \\
\hline
\end{tabular}


Table 2 Average soil $\mathrm{C}$, microbial biomass $\mathrm{N}\left(\mathrm{N}_{\text {mic }}\right)$, and activity of protease, $\beta$-glucosidase, and $\beta$-glucosaminidase in the top $30 \mathrm{~cm}$ of the soil profile

\begin{tabular}{|c|c|c|c|c|c|c|c|c|c|c|c|}
\hline \multirow[t]{2}{*}{ Soil property } & \multirow[t]{2}{*}{ Tillage } & \multicolumn{10}{|l|}{ Date } \\
\hline & & $04 / 06$ & & $05 / 14$ & & $07 / 02$ & & $08 / 03$ & & $09 / 03$ & \\
\hline Total soil $\mathrm{C}\left(\mathrm{g} \mathrm{kg}^{-1}\right)$ & $\begin{array}{l}\text { ST } \\
\text { CT }\end{array}$ & $\begin{array}{l}10.4 \\
10.8\end{array}$ & a & $\begin{array}{l}10.8 \\
10.1\end{array}$ & $\mathrm{a}$ & $\begin{array}{l}10.7 \\
10.5\end{array}$ & $\mathrm{a}$ & $\begin{array}{l}10.6 \\
10.2\end{array}$ & a & $\begin{array}{l}10.9 \\
10.3\end{array}$ & a \\
\hline $\mathrm{N}_{\text {mic }}\left(\mathrm{mg} \mathrm{kg}^{-1}\right)$ & $\begin{array}{l}\text { ST } \\
\text { CT }\end{array}$ & $\begin{array}{l}19.1 \\
21.8\end{array}$ & $\mathrm{~b}$ & $\begin{array}{l}30.2 \\
24.2\end{array}$ & $a b$ & $\begin{array}{l}29.0 \\
29.2\end{array}$ & a & $\begin{array}{l}5.4 \\
8.7\end{array}$ & $\mathrm{c}$ & $\begin{array}{r}11.5 \\
9.2\end{array}$ & $\mathrm{c}$ \\
\hline Protease activity (mg tyrosine $\mathrm{kg}^{-1} \mathrm{~h}^{-1}$ ) & $\begin{array}{l}\text { ST } \\
\text { CT }\end{array}$ & $\begin{array}{l}57.4 \\
51.9\end{array}$ & $\mathrm{a}$ & $\begin{array}{l}44.8 \\
48.2\end{array}$ & $\mathrm{a}$ & $\begin{array}{l}47.2 \\
45.7\end{array}$ & a & $\begin{array}{l}39.7 \\
43.5\end{array}$ & $\mathrm{a}$ & $\begin{array}{l}48.7 \\
45.8\end{array}$ & $\mathrm{a}$ \\
\hline$\beta$-glucosidase activity (mg $p$-nitrophenol kg ${ }^{-1} \mathrm{~h}^{-1}$ ) & $\begin{array}{l}\text { ST } \\
\text { CT }\end{array}$ & $\begin{array}{l}174 \\
234\end{array}$ & $\mathrm{c}$ & $\begin{array}{l}293 \\
290\end{array}$ & $\mathrm{a}$ & $\begin{array}{l}204 \\
304\end{array}$ & $a b c$ & $\begin{array}{l}191 \\
209\end{array}$ & $\mathrm{bc}$ & $\begin{array}{l}224 \\
272\end{array}$ & al \\
\hline$\beta$-glucosaminidase activity ( $\mathrm{mg} p$-nitrophenol $\mathrm{kg}^{-1} \mathrm{~h}^{-1}$ ) & $\begin{array}{l}\text { ST } \\
\text { CT }\end{array}$ & $\begin{array}{l}58.6 \\
55.6\end{array}$ & $a b$ & $\begin{array}{l}72.6 \\
52.2\end{array}$ & $a b$ & $\begin{array}{l}50.4 \\
51.3\end{array}$ & $\mathrm{~b}$ & $\begin{array}{l}56.9 \\
51.9\end{array}$ & $a b$ & $\begin{array}{l}63.4 \\
64.8\end{array}$ & a \\
\hline
\end{tabular}

Significant differences $(P<0.05)$ between sampling dates are indicated with different letters. Italicized areas highlighting two values indicate significant differences between standard tillage (ST) and conservation tillage (CT)

layers. In the ST soil, $\mathrm{N}_{\text {mic }}$ had increased in the whole profile, with small differences between depths. By July, $\mathrm{N}_{\text {mic }}$ had decreased considerably in both tillage systems in the top $5 \mathrm{~cm}$ and continued decreasing at all depths until August. In August and September, the differences between tillage treatments and depths were small and not significant.
In the top $5 \mathrm{~cm}, \mathrm{~N}_{\text {mic }}$ was slightly lower compared to the 5 15-cm layer. The stratification ratio also fluctuated widely in both tillage systems, which was mainly the result of the changes in the top $5 \mathrm{~cm}$ (Table 3).

In general, enzyme activities were higher in the $\mathrm{CT}$ soil compared to the ST soil; however, only few differences

\section{a Total C (g kg" dry soll)}

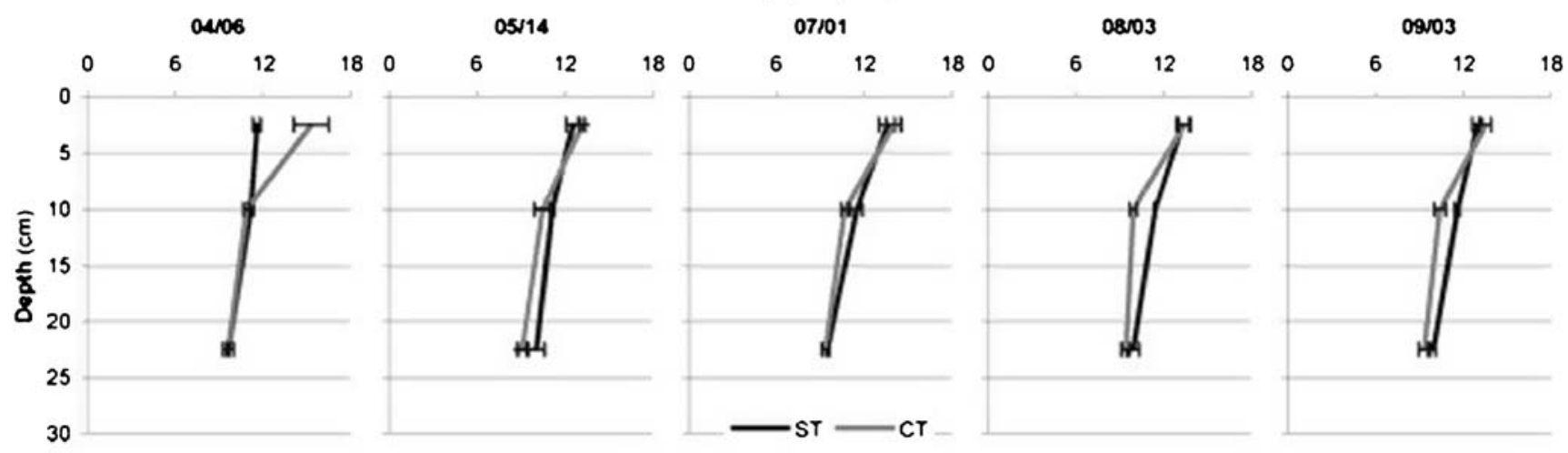

b

Microbial biomass $\mathrm{N}$ (ma Nka" ars soll)

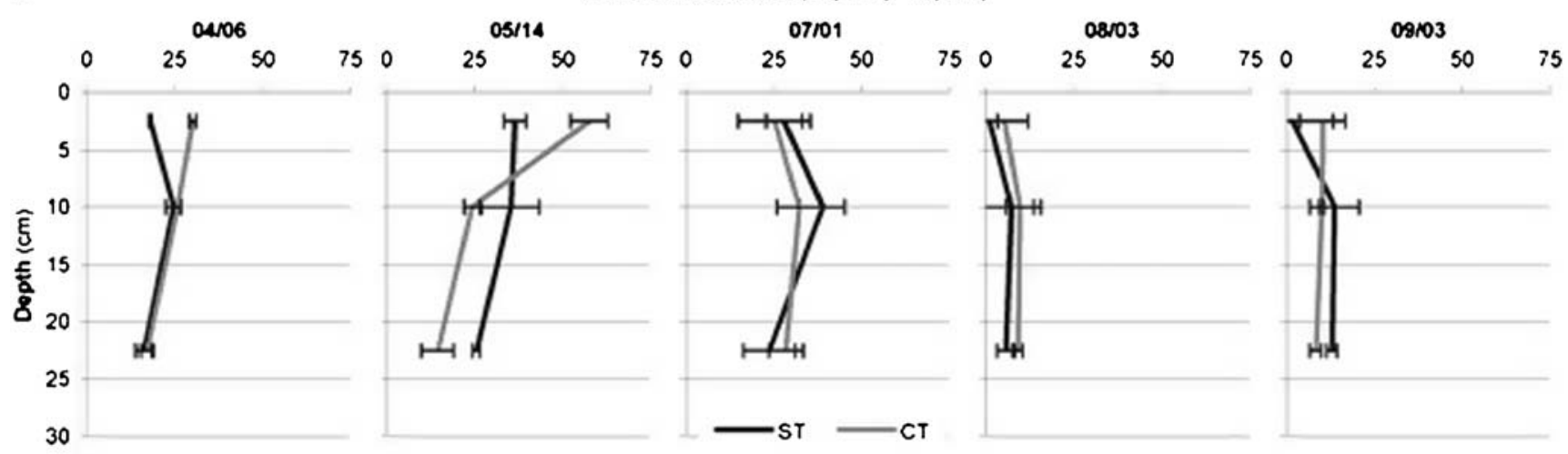

Fig. 1 Total soil C content (a) and soil microbial biomass N (b) as affected by tillage system, depth, and sampling date. $S T=$ standard tillage; $C T=$ conservation tillage. Data shown are means $(n=3) \pm$ standard error of the means $(\mathrm{SE})$ 
Table 3 Stratification ratios for soil $\mathrm{C}$, microbial biomass $\mathrm{N}$ $\left(\mathrm{N}_{\text {mic }}\right)$, and activity of protease, $\beta$-glucosidase, and $\beta$ glucosaminidase

Significant differences $(P<0.05)$ between sampling dates are indicated with different letters. Italicized areas highlighting two values indicate significant differences between standard tillage (ST) and conservation tillage (CT)

$b d \mathrm{~N}_{\text {mic }}$ in the top $5 \mathrm{~cm}$ below detection limit

\begin{tabular}{|c|c|c|c|c|c|c|c|c|c|c|c|}
\hline \multirow{3}{*}{$\begin{array}{l}\text { Soil property } \\
\text { Total soil C }\end{array}$} & \multirow{3}{*}{$\begin{array}{l}\text { Tillage } \\
\\
\text { ST } \\
\text { CT }\end{array}$} & \multicolumn{10}{|l|}{ Date } \\
\hline & & \multicolumn{2}{|l|}{$04 / 06$} & \multicolumn{2}{|c|}{$05 / 14$} & \multicolumn{2}{|l|}{$07 / 02$} & \multicolumn{2}{|l|}{$08 / 03$} & \multicolumn{2}{|l|}{$09 / 03$} \\
\hline & & $\begin{array}{l}1.20 \\
1.60\end{array}$ & a & $\begin{array}{l}1.25 \\
1.46\end{array}$ & $\mathrm{a}$ & $\begin{array}{l}1.43 \\
1.50\end{array}$ & a & $\begin{array}{l}1.35 \\
1.44\end{array}$ & $\mathrm{a}$ & $\begin{array}{l}1.31 \\
1.46\end{array}$ & a \\
\hline $\mathrm{N}_{\text {mic }}$ & $\begin{array}{l}\text { ST } \\
\text { CT }\end{array}$ & $\begin{array}{l}1.17 \\
1.96\end{array}$ & a & $\begin{array}{l}1.44 \\
5.01\end{array}$ & $\mathrm{a}$ & $\begin{array}{l}1.58 \\
1.00\end{array}$ & a & $\begin{array}{l}\text { bd } \\
0.70\end{array}$ & & $\begin{array}{l}0.33 \\
1.72\end{array}$ & a \\
\hline Protease activity & $\begin{array}{l}\text { ST } \\
\text { CT }\end{array}$ & $\begin{array}{l}0.99 \\
2.25\end{array}$ & a & $\begin{array}{l}2.52 \\
5.29\end{array}$ & $\mathrm{a}$ & $\begin{array}{l}0.53 \\
2.65\end{array}$ & a & $\begin{array}{l}1.83 \\
1.89\end{array}$ & $\mathrm{a}$ & $\begin{array}{l}1.13 \\
1.98\end{array}$ & a \\
\hline$\beta$-glucosidase activity & $\begin{array}{l}\text { ST } \\
\text { CT }\end{array}$ & $\begin{array}{l}1.88 \\
5.04\end{array}$ & a & $\begin{array}{l}1.79 \\
5.74\end{array}$ & $\mathrm{a}$ & $\begin{array}{l}1.92 \\
5.50\end{array}$ & a & $\begin{array}{l}1.75 \\
5.46\end{array}$ & $\mathrm{a}$ & $\begin{array}{l}1.86 \\
5.19\end{array}$ & a \\
\hline$\beta$-glucosaminidase activity & $\begin{array}{l}\text { ST } \\
\text { CT }\end{array}$ & $\begin{array}{l}1.13 \\
2.91\end{array}$ & a & $\begin{array}{l}1.19 \\
2.09\end{array}$ & $\mathrm{a}$ & $\begin{array}{l}1.74 \\
2.24\end{array}$ & a & $\begin{array}{l}1.60 \\
1.71\end{array}$ & $\mathrm{a}$ & $\begin{array}{l}1.44 \\
2.99\end{array}$ & a \\
\hline
\end{tabular}

were significant. On April 6 and September 3, $\beta$ glucosidase activity was significantly increased in the CT soil, while, on May 15, $\beta$-glucosaminidase was higher in the ST soil. These two enzyme activities also changed significantly over time, while protease activity remained relatively constant (Table 2). The changes in enzyme activity with depth were similar for the three enzymes measured (Fig. 2). In general, enzyme activities were highest in the top $5 \mathrm{~cm}$ and decreased with depth. In the top $5 \mathrm{~cm}$ of the profile, enzyme activities were higher under CT than ST, while in the 5-15-cm layer, the opposite trend was observed. In the $15-30-\mathrm{cm}$ layer, the differences between tillage treatments were minimal. In contrast to $\mathrm{N}_{\text {mic }}$, enzyme activities did not decrease in the top $5 \mathrm{~cm}$ of the soil towards the end of the cropping season. The activity of the three enzymes per unit $\mathrm{N}_{\text {mic }}$ was relatively stable from April to July with no clear trend related to depth or sampling date (data not shown). However, enzyme activity per unit $\mathrm{N}_{\text {mic }}$ increased more than tenfold in the top $5 \mathrm{~cm}$ in August and September, while the increase in the subsoil was less dramatic. The stratification ratio for all three enzymes was higher in the CT soil than in the ST soil at all sampling dates. The differences in the stratification ratio between tillage treatments for protease and $\beta$ glucosaminidase were only significant in April, while the differences in the $\beta$-glucosidase stratification ratio were significant at all sampling dates. The stratification ratio of $\beta$-glucosidase in the ST soil averaged 1.84 over all sampling and was never above 2.0, while it averaged 5.39 in the CT soil without any value below 5.0 (Table 3 ).

\section{Discussion}

In general, 5 years of CT had little effect on the average soil $\mathrm{C}$ content and its distribution in the soil profile. Total soil $\mathrm{C}$ also changed little during the growing season, indicating that factors other than tillage had only small effects as well. Reduced tillage intensity has been found to increase soil organic matter content (Logan et al. 1991; Cannell and Hawes 1994) and to result in physically and chemically stratified soils, with more nutrients and organic matter localized near the surface (Hendrix et al. 1986; West and Post 2002). The small effects in our study are most likely due to the short duration of the tillage experiment.

In contrast to total soil $\mathrm{C}, \mathrm{N}_{\text {mic }}$ fluctuated widely during the cropping season. Two factors, namely cover crop residue availability and soil moisture, appeared to be mainly responsible for these fluctuations in the size and distribution of $\mathrm{N}_{\text {mic }}$. The increase in $\mathrm{N}_{\text {mic }}$ from May to July seems to be the result of the availability of $\mathrm{C}$ and nutrients from the cover crop residue. The incorporation of cover crop residue in the ST system had a positive effect on $\mathrm{N}_{\text {mic }}$ in the 5-15-cm layer, while the residue, which was left on the surface in the CT system, increased $\mathrm{N}_{\text {mic }}$ only in the top $5 \mathrm{~cm}$ of the profile. Later in the season, $\mathrm{N}_{\text {mic }}$ decreased in both tillage treatments, especially in the top $5 \mathrm{~cm}$. This is most likely due to the very low soil moisture content in this layer. At a location with similar soil type and management systems, Gunapala and Scow (1998) also found a significant and positive correlation between soil moisture and the size of the microbial biomass across different farming systems. These results are in agreement with Staley et al. (1988), who reported a significant effect of soil moisture on $\mathrm{C}_{\text {mic }}$ in the surface soil layer. In addition to the temporal fluctuations, the spatial variability in $\mathrm{N}_{\text {mic }}$ was also large. Under the conditions of the present study, $\mathrm{N}_{\text {mic }}$ was therefore too sensitive to environmental factors to be a useful indicator of tillage-induced changes in soil quality.

Different soil enzyme activities have been found to be sensitive indicators of tillage-induced changes in soil quality (Dick 1994; Ekenler and Tabatabai 2003a, b). In our study, soil enzyme activities were generally more sensitive to tillage-induced effects than total soil $\mathrm{C}$ and were less affected by environmental factors, especially the dry topsoil later in the season, than was $\mathrm{N}_{\text {mic }}$. During the first half of the growing season, the distribution of enzyme activities in the soil profile resembled the distribution of 
a

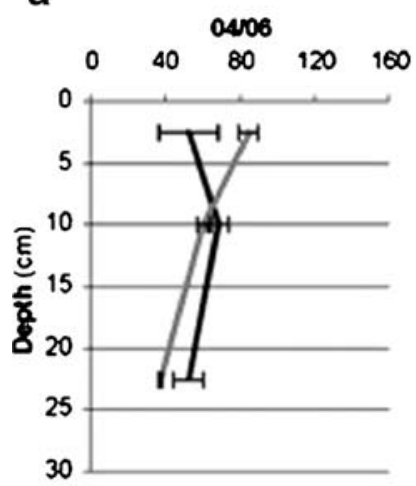

b

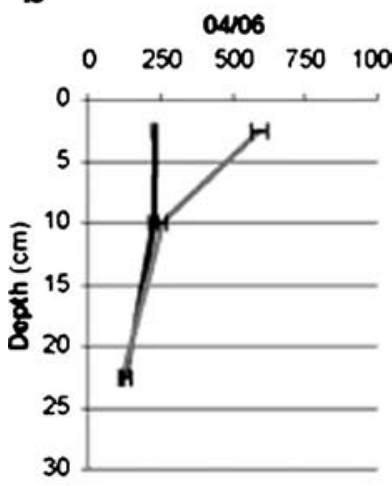

C

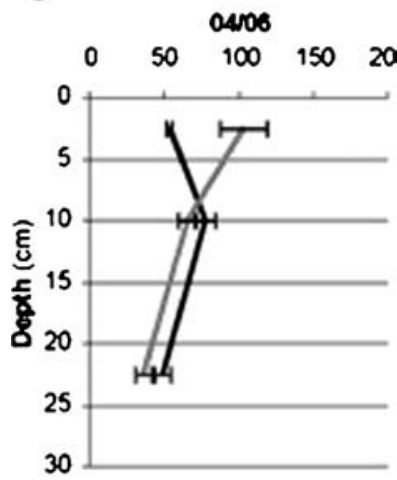

Protease activity (mg Tyrosine kg ' dry sol h'.')

0514

07101
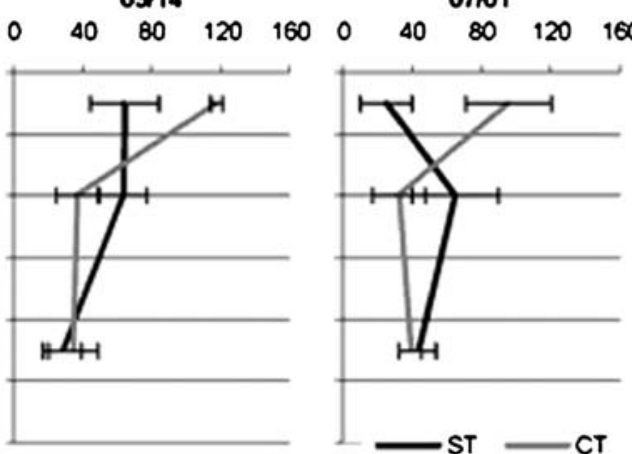

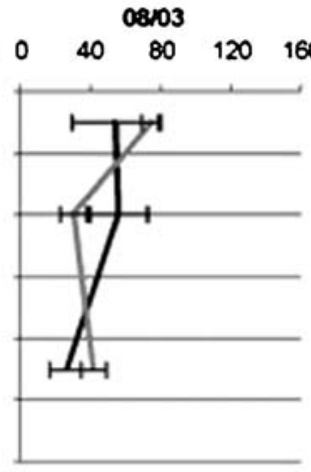

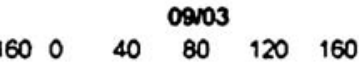

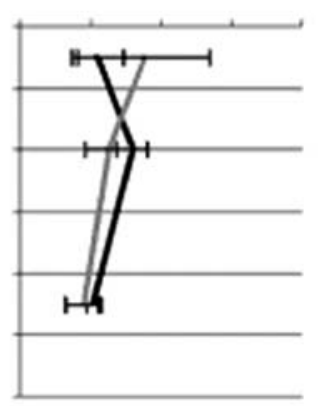

B-glucosidase activity (mg D.Nitophenol kg ${ }^{\circ}$ dry sod h ${ }^{\prime \prime}$ )

05114

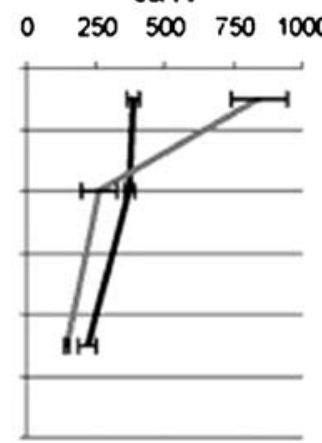

07101 $\begin{array}{llll}250 & 500 & 750 & 1000\end{array}$
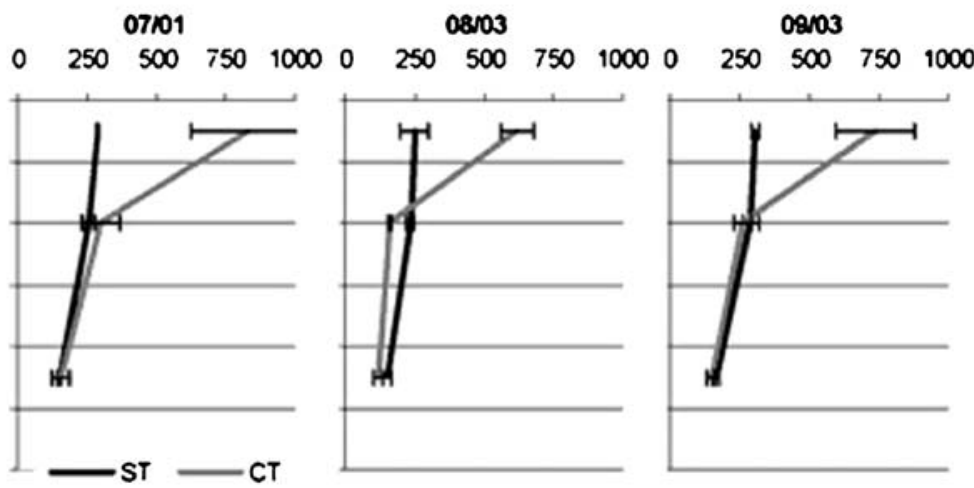

\section{B-glucosaminidase activity (mg p.Nerophenol kg ' ory soil h ')}

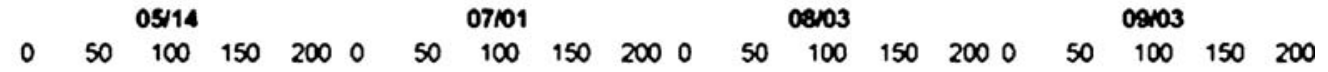

0803
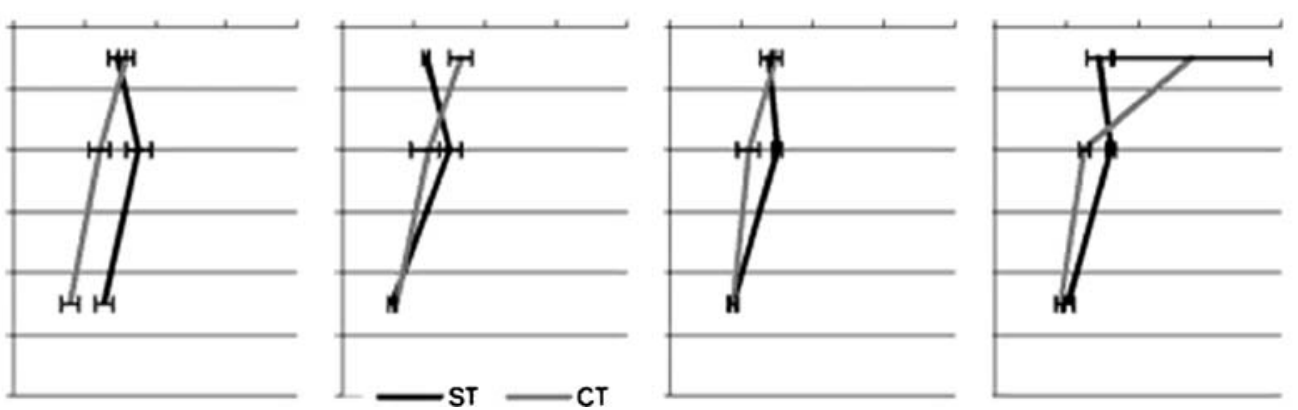

Fig. 2 Activity of protease (a), $\beta$-glucosidase (b), and $\beta$-glucosaminidase (c) as affected by tillage system, depth, and sampling date. $S T=$ standard tillage; $C T=$ conservation tillage. Data shown are means $(n=3) \pm \mathrm{SE}$

total soil $\mathrm{C}$ and $\mathrm{N}_{\text {mic }}$. This is in line with a number of studies which reported strong correlations between enzyme activities on one hand and $\mathrm{N}_{\text {mic }}$ (Doran 1980; Madejón et al. 2007) and soil organic $\mathrm{C}$ on the other hand (Dick 1984; Deng and Tabatabai 1996; Acosta-Martínez et al. 2003) and shows that enzymes are mainly produced by soil microorganisms to degrade available substrates.

During the second half of the season, enzyme activities were much less affected by the dry top soil than $\mathrm{N}_{\text {mic }}$, which resulted in a considerable increase in enzyme activity per unit $\mathrm{N}_{\text {mic }}$. Extracellular enzymes may have been stabilized and protected by soil colloids (Burns 1982).
Therefore, the elevated levels of enzyme activity in the dry soil may have been the result of low degradation rates of enzymes produced earlier in the season and not of continuous production.

While the differences in enzyme activities between tillage systems were larger than for total soil $\mathrm{C}$, the higher variability of the data prevented most of the observed differences in protease and $\beta$-glucosaminidase activity from being significant. An exception was $\beta$ glucosidase activity. While the fluctuations in total $\beta$ glucosidase activity in the top $30 \mathrm{~cm}$ of the soil profile during the season were similar to the other enzyme 
activities, the stratification ratio was remarkably constant and significantly increased in the CT soil compared to the ST soil at all sampling dates. Other studies have also found $\beta$-glucosidase activity to be increased by reduced tillage. However, $\beta$-glucosidase activity did not appear to be more sensitive to tillage-induced changes in soil quality than other enzyme activities in these studies (Deng and Tabatabai 1996; Curci et al. 1997; Alvear et al. 2005; Roldán et al. 2005; Madejón et al. 2007). Therefore, our result may be site specific.

\section{Conclusions}

Under the conditions of our study, enzyme activities, but not $\mathrm{N}_{\text {mic }}$, were more sensitive to tillage-induced changes than total soil C. Therefore, hypothesis 1 was only supported with respect to enzyme activities. In line with hypothesis 2 , both enzyme activities and $\mathrm{N}_{\text {mic }}$ were much more affected by environmental factors than total soil $\mathrm{C}$, resulting in a larger spatial and temporal variability. Using the stratification ratio instead of the average values reduced some of the variability in enzyme activities but not in $\mathrm{N}_{\text {mic }}$ (hypothesis 3). However, only the stratification ratio for $\beta$ glucosidase activity resulted in significant differences between tillage treatments at each sampling date. Therefore, in studies with small tillage-induced effects, enzyme activities from a single sampling date have to be interpreted with caution, as the differences observed may not be solely caused by the tillage treatments imposed.

Acknowledgement We would like to thank Israel Herrera and Dennis Bryant for their support with field operations and Timothy Doane and Patricia Lazicki for their help with laboratory procedures. We also thank Randy Dahlgren, Kate Scow, the editor-in-chief, Paolo Nannipieri, and three anonymous reviewers for valuable suggestions on the manuscript. This research was in part supported by a research award from the UC Davis Agricultural Sustainability Institute.

Open Access This article is distributed under the terms of the Creative Commons Attribution Noncommercial License which permits any noncommercial use, distribution, and reproduction in any medium, provided the original author(s) and source are credited.

\section{References}

Acosta-Martínez V, Zobeck TM, Gill TE, Kennedy AC (2003) Enzyme activities and microbial community structure in semiarid agricultural soils. Biol Fertil Soils 38:216-227

Alvear M, Rosas A, Rouanet JL, Borie F (2005) Effects of three soil tillage systems on some biological activities in an ultisol form southern Chile. Soil Tillage Res 82:195-202

Bandick AK, Dick RP (1999) Field management effects on soil enzyme activities. Soil Biol Biochem 31:1471-1479

Bausenwein U, Gattinger A, Langer U, Embacher A, Hartmann HP, Sommer M, Munch JC, Schloter M (2008) Exploring soil microbial communities and soil organic matter: variability and interactions in arable soils under minimum tillage practice. Appl Soil Ecol 40:67-77

Burns RG (1982) Enzyme activity in soil: location and a possible role in microbial ecology. Soil Biol Biochem 14:423-427

Cabrera ML, Beare MH (1993) Alkaline persulfate oxidation for determining total nitrogen in microbial biomass extracts. Soil Sci Soc Am J 57:1007-1012

Cannell RQ, Hawes JD (1994) Trends in tillage practices in relation to sustainable crop production with special reference to temperate climates. Soil Tillage Res 30:245-282

Curci M, Pizzigallo MDR, Crecchio C, Mininni R, Ruggiero P (1997) Effects of conventional tillage on biochemical properties of soils. Biol Fertil Soils 25:1-6

Deng SP, Tabatabai MA (1996) Effect of tillage and residue management on enzyme activities in soils II. Glycosidases. Biol Fertil Soils 22:208-213

Denison FD, Bryant DC, Kearney TE (2004) Crop yields over the first nine years of LTRAS, a long-term comparison of field crop systems in a Mediterranean climate. Field Crops Res 86:267277

Dick WA (1984) Influence of long-term tillage and crop rotation combinations on soil enzyme activities. Soil Sci Soc Am J 48:569-574

Dick RP (1992) A review: long-term effects of agricultural systems on soil biochemical and microbial parameters. Agric Ecosys Environ 40:25-36

Dick RP (1994) Soil enzyme activities as indicators of soil quality. In: Doran JW, Coleman DC, Bezdicek DF, Stewart BA (eds) Defining soil quality for a sustainable environment. Soil Science Society of America, Madison, pp 107-124

Dilly O, Blume HP, Munch JC (2003) Soil microbial activities in Luvisols and Anthrosols during 9 years of region-typical tillage and fertilization practices in northern Germany. Biogeochemistry 65:319-339

Doane TA, Horwath WR (2003) Spectrophotometric determination of nitrate with a single reagent. Anal Lett 36:2713-2722

Doran JW (1980) Soil microbial and biochemical changes associated with reduced tillage. Soil Sci Soc Am J 44:765-771

Ekenler M, Tabatabai MA (2003a) Tillage and residue management effects on $\beta$-glucosaminidase activity in soils. Soil Biol Biochem 35:871-874

Ekenler M, Tabatabai MA (2003b) Effects of liming and tillage systems on microbial biomass and glycosidases in soils. Biol Fertil Soils 39:51-61

Franzluebbers AJ (2002) Soil organic matter stratification ratio as an indicator of soil quality. Soil Tillage Res 66:95-106

Franzluebbers AJ, Hons FM, Zuberer DA (1994) Seasonal changes in soil microbial biomass and mineralizable $\mathrm{C}$ and $\mathrm{N}$ in wheat management systems. Soil Biol Biochem 26:14691475

Gee GW, Bauder JW (1986) Particle-size analysis. In: Klute A (ed) Methods of soil analysis. Part 1. Physical and mineralogical methods. American Society of Agronomy. Soil Science Society of America, Madison, pp 383-411

Gunapala N, Scow KM (1998) Dynamics of soil microbial biomass and activity in conventional and organic farming systems. Soil Biol Biochem 30:805-816

Hendrix PF, Parmelee RW, Crossley DA, Coleman DC, Odum EP, Groffman PM (1986) Detritus food webs in conventional and notill agroecosystems. BioScience 36:374-380

Horwath WR, Paul EA (1994) Microbial biomass. In: Weaver RW, Angle S, Bottomley P, Bezdiecek D (eds) Methods of soil analysis. Part 2. Microbiological and biochemical properties. Soil Science Society of America, Madison, pp $753-773$ 
Kandeler E, Tscherko D, Spiegel H (1999) Long-term monitoring of microbial biomass, $\mathrm{N}$ mineralisation and enzyme activities of a Chernozem under different tillage managements. Biol Fertil Soils 28:343-351

Karlen DL, Wollenhaupt NC, Erbach DC, Berry EC, Swan JB, Eash NS, Jordahl JL (1994) Long-term tillage effects on soil quality. Soil Tillage Res 32:313-327

Ladd JN, Butler JHA (1972) Short-term assays of soil proteolytic enzyme activities using proteins and dipeptide derivatives as substrates. Soil Biol Biochem 4:19-30

Littell RC, Milliken GA, Stroup WW, Wolfinger RD, Schabenberger O (2006) SAS for mixed models. SAS Institute, Cary

Logan TJ, Lal R, Dick WA (1991) Tillage systems and soil properties in North America. Soil Tillage Res 20:241-270

Madejón E, Moreno F, Murillo JM, Pelegrín F (2007) Soil biochemical response to long-term conservation tillage under semi-arid Mediterranean conditions. Soil Tillage Res 94:346352

Omidi H, Tahmasebi Z, Torabi H, Miransari M (2008) Soil enzymatic activities and available $\mathrm{P}$ and $\mathrm{Zn}$ as affected by tillage practices, canola (Brassica napus L.) cultivars and planting dates. Eur J Soil Biol 44:443-450
Parham JA, Deng SP (2000) Detection, quantification and characterization of $\beta$-glucosaminidase activity in soil. Soil Biol Biochem 32:1183-1190

Roldán A, Salinas-García JR, Alguacil MM, Díaz E, Caravaca F (2005) Soil enzyme activities suggest advantages of conservation tillage practices in sorghum cultivation under subtropical conditions. Geoderma 129:178-185

SAS Institute (1990) SAS/STAT user's guide, version 6. SAS Institute, Cary

Soil Survey Staff (1997) Official Soil Series Descriptions. http://soils. usda.gov/technical/classification/osd/index.html. Accessed 23 Oct 2007

Staley TE, Edwards WM, Scott CL, Owens LB (1988) Soil microbial biomass and organic component alterations in a no-tillage chronosequence. Soil Sci Soc Am J 52:998-1005

Tabatabai MA (1994) Soil enzymes. In: Weaver RW, Angle S, Bottomley P, Bezdiecek D (eds) Methods of soil analysis. Part 2. Microbiological and biochemical properties. Soil Science Society of America, Madison, pp 775-833

West TO, Post WM (2002) Soil organic carbon sequestration rates by tillage and crop rotation: a global data analysis. Soil Sci Soc Am J 66:1930-1946 